\title{
Long-term effect of farming systems on the yield of crop rotation and soil nutrient content
}

\author{
Indrek Keres ${ }^{1}$, Maarika Alaru ${ }^{1}$, Liina Talgre ${ }^{1}$, Viacheslav Eremeev ${ }^{1}$, Anne Luik $^{2}$ and Evelin Loit ${ }^{1}$ \\ ${ }^{1}$ Chair of Crop Science and Plant Biology, Institute of Agricultural and Environmental Sciences, \\ Estonian University of Life Sciences, Fr. R. Kreutzwaldi 5, 51006 Tartu, ESTONIA \\ ${ }^{2}$ Chair of Plant Health, Institute of Agricultural and Environmental Sciences, \\ Estonian University of Life Sciences, Fr.R. Kreutzwaldi 5, Tartu 51006, ESTONIA \\ e-mail: Indrek.Keres@emu.ee
}

\begin{abstract}
The effects of organic (manure, cover crop) and mineral fertilisers on total yield, soil phosphorus (P) and potassium (K) dynamics and soil pH changes were studied over 10 years. Five field crops (spring barley, red clover, winter wheat, field pea, potato) were grown organically and conventionally in rotation. The total yield of the five crops fertilized similarly was $24-25 \%$ higher in conventionally fertilised treatments than in organic treatments. The higher yielding conventionally fertilised treatments (annual total yield $29.0-29.8 \mathrm{t} \mathrm{ha}^{-1}$ ) removed $12-18 \mathrm{~kg} \mathrm{ha}^{-1} \mathrm{P}$ and $45-73$ $\mathrm{kg} \mathrm{ha}^{-1} \mathrm{~K}$ per year, which was respectively $28-35 \%$ and $28-40 \%$ higher than organic treatments. The soil became more acidic in the conventional system ( $\mathrm{pH} 5.4-5.9$ versus 5.9-6.3). The highest annual $\mathrm{P}$ and $\mathrm{K}$ uptake was by potato, followed by winter wheat. Use of winter cover crops and composted cattle manure in the organic system did not maintain the levels of $\mathrm{P}$ and $\mathrm{K}$ in the soil at baseline.
\end{abstract}

Key words: total yield, farming system, organic, conventional, manure, cover crop

\section{Introduction}

Agriculture faces many challenges if it is to maximize yields while operating in an environmentally sustainable manner (Ricroch et al. 2016). One of the key challenges is maintaining soil fertility which is fundamental in determining the productivity of all farming systems. Optimisation of the nutrient cycling of agro-ecosystems and development of a suitable fertility strategy is a serious challenge for farming systems. High yields and intensive cropping make significant demands for nutrients from the soil, which leads to depletion of reserves (Murugappan et al. 2007). To improve the biological, chemical and physical properties of the soil, crop rotation, winter cover crops and composted manure can be used to maintain soil organic matter and fertility (Baldwin 2006, Doltra and Olesen 2013).

In past decades, organic farming has increased rapidly in Europe (EC 2014). The aim of organic agriculture is to produce food of high nutritional quality, in sufficient quantity and in an environmentally friendly way. Comparing organic with conventional farming, a fundamental difference between their management is the way in which challenges are addressed. Organic farming systems are designed with the aim of maintaining nutrients in organic reservoirs or in bioavailable mineral forms instead of supplying nutrients through frequent fertiliser additions. This is achieved by cycling nutrients through organic reservoirs (Wander 2015). The results of several long-term studies have shown that the addition of compost improves soil physical properties by decreasing bulk density and increasing the soil water holding capacity (Weber et al. 2007). To improve the biological, chemical and physical properties of the soil, crop rotation, winter cover crops and composted manure are used to maintain soil organic matter and fertility (Baldwin 2006, Doltra and Olesen 2013). Moreover, in comparison with mineral fertilisers, compost produces significantly greater increases in soil organic carbon and delivers a wider range of plant nutrients (García-Gil et al. 2000, Bulluck et al. 2002, Nardi et al. 2004, Weber et al. 2007). Long-term beneficial effects of composted materials are also observed in soil humic substances, as well as in soil sorption properties (Weber et al. 2007). Conventional fertiliser management guidelines are based on assessments of plant-available nutrients in the soil. Crop nutrient uptake and crop yields are the principal factors that determine optimal fertilisation practices (Ju and Christie 2011). Therefore, it is very important to apply fertilisers in an efficient way to minimize loss and to improve the efficiency of nutrient use (Li et al. 2009).

Several articles have dealt with the long-term effects of organic and conventional cultivation on soil microbiological activity (Fliessbach et al. 2000, Mäder et al. 2000, Oehl et al. 2003, Esperschütz et al. 2007), but less research has been published on changes in soil phosphorus (P) and potassium (K) content and pH after long-term organic cultivation (Gosling and Shepherd 2005, Kirchmann et al. 2007, Kaš et al. 2016). This article discusses the long-term effects of organic and mineral fertilisers on soil $\mathrm{P}, \mathrm{K}$ and $\mathrm{pH}$ level dynamics in organic and conventional farming systems over 10 years. We investigated whether long-term winter cover crop cultivation and fertilisation with manure 


\section{AGRICULTURAL AND FOOD SCIENCE}

I. Keres et al. (2020) 29: 210-221

have been able to prevent a decrease in soil $\mathrm{P}$ and $\mathrm{K}$ levels and to improve the soil $\mathrm{pH}$ in a crop rotation that has quite a high nutrient requirement. $\mathrm{P}$ and $\mathrm{K}$ in soils are present in different fractions some of which are more available to plants than others (Kulhánek et al. 2009, Vanden Nest et al. 2015, Srinivasarao and Srinivas 2017). Soil pH has also an effect on the availability of $\mathrm{P}$ and $\mathrm{K}$ to plants. The most mobile and plant-available fraction of $\mathrm{P}$ and $\mathrm{K}$ is soil solution $\mathrm{P}$ and $\mathrm{K}$, followed by exchangeable $\mathrm{P}$ and $\mathrm{K}$, fast release fixed $\mathrm{P}$ and $\mathrm{K}$, and slow release fixed $\mathrm{P}$ and $\mathrm{K}$.

Long-term field trials are important for the study of soil processes under natural conditions. The aim of this study was to compare the long-term effects of organic and mineral fertilisers on (i) total yield of a five course crop rotation, with all crops present every year, (ii) soil pH changes and (iii) soil plant available $\mathrm{P}$ and $\mathrm{K}$ dynamics in organic and conventional farming systems over 10 years and iv) whether long-term use of winter cover crops and well composted manure ensured the maintenance of soil fertility.

\section{Materials and methods \\ Experiment set up}

A rotational experiment comparing the effect of organic and conventional management on the yield of field crops and soil properties was established at the Estonian University of Life Sciences ( $58^{\circ} 22^{\prime} \mathrm{N}, 2^{\circ} 40^{\prime} \mathrm{E}$; near Tartu) in 2008. The rotation consists of spring barley (Hordeum vulgare L.) undersown with red clover- red clover (Trifolium pratense L.)- winter wheat (Triticum aestivum L.)- field pea (Pisum sativum L.)- potato (Solanum tuberosum L.) rotation. The soil is a Stagnic Luvisol (IUSS WG WRB 2015) (WRB, Deckers et al. 2002), (sandy loam surface texture, $\mathrm{C} 1.38 \%$, and $\mathrm{N} 0.13 \%, \mathrm{pH}_{\mathrm{KCl}} 6.0$ ). The field experiment has a systematic block design with four replicates that included the following treatments: organic fertilisation and mineral fertilisation. In the conventional system there were four subplots $(10 \times 6 \mathrm{~m})$ with different fertiliser (pure ammonium nitrate, $\mathrm{NH}_{4} \mathrm{NO}_{3}$ ) application rates (N0, N1, N2, N3). The organic system was divided into 3 fertility building treatments: Org 0, Org I and Org II Fig S1). The experimental design was described by Alaru et al. (2014). The data in the present study concerned the period 2008-2017, i.e. two rotation periods, lasting ten years.

The treatment NO was the control treatment for the conventional system, without mineral fertilisers, but with pesticides. Plant protection with pesticides can potentially increase yield compared to Org 0 . This may affect the $\mathrm{P}$ and $\mathrm{K}$ balances as well. The other three conventional treatments N1, N2 and N3, had P and K fertilisers applied at sowing at the rate of 25 and $95 \mathrm{~kg} \mathrm{ha}^{-1}$, respectively (amounts of $\mathrm{P}$ and $\mathrm{K}$ were similar in all treatments, Kemira and Yara Mila commercial fertilisers were used). In conventional treatments the mineral $\mathrm{N}$ fertiliser $\mathrm{NH}_{4} \mathrm{NO}_{3}$ was applied once/or twice during growth (N1 $=40-50 \mathrm{~kg} \mathrm{~N} \mathrm{ha}^{-1} ; \mathrm{N2}=80-100 \mathrm{~kg} \mathrm{~N} \mathrm{ha}^{-1}$ and N3 $=120-150 \mathrm{~kg} \mathrm{~N} \mathrm{ha}^{-1}$ ). A lower $\mathrm{N}$ application rate was used for the barley crop with undersown red clover; red clover alone did not receive any mineral fertilisers. Peas received mineral $\mathrm{N}$ at $20 \mathrm{~kg} \mathrm{~N} \mathrm{ha}^{-1}$ in N1, N2 and N3 treatments.

The first organic treatment (Org 0) was a control for the organic system, without organic fertilisers. In the second organic treatment (Org I) cover crops were used as a green manure in winter: after crops of winter wheat, potato and pea, the cover crops winter rye (Secale cereale L.) + winter oilseed rape (Brassica napus ssp. oleifera var. biennis) mixture, winter rye and winter oilseed rape, respectively, were sown. Cover crops were ploughed into the soil as soon as possible after the snow melted in April. In the third organic treatment (Org II), fully composted cattle manure was added once during the first crop cycle, before potato. Manure $\left(40 \mathrm{t} \mathrm{ha}^{-1}\right)$ was ploughed into the soil to a depth of 20-23 cm at the end of September or beginning of October before sowing winter oilseed rape as a cover crop. In the second crop cycle period (2013-2017) the timing and rate of manure application was changed: the first application was in early spring before winter wheat re-growth at a rate of $10 \mathrm{t} \mathrm{ha}^{-1}$, the second application before barley sowing at a rate of $10 \mathrm{t} \mathrm{ha}^{-1}$ and the third application before potato sowing at a rate of $20 \mathrm{t} \mathrm{ha} \mathrm{A}^{-1}$. As the content of dry matter (DM) and nutrients in the composted cattle manure were variable, the N, P, K amounts applied with manure also varied (Table 1).

Table 1. N, P and K applied to the organic system in manure (2008-2017)

\begin{tabular}{lllll}
\hline Crop rotation & Crop & $\mathrm{N}\left(\mathrm{kg} \mathrm{ha}^{-1}\right)$ & $\mathrm{P}\left(\mathrm{kg} \mathrm{ha}^{-1}\right)$ & $\left.\mathrm{K}(\mathrm{kg} \mathrm{ha})^{-1}\right)$ \\
\hline I/ 2008-2012 & Potato & $165-179$ & $75-90$ & $130-145$ \\
II/ 2013-2017 & Winter wheat & $44-54$ & $8-18$ & $17-43$ \\
& Barley with red clover & $44-54$ & $8-18$ & $17-43$ \\
& Potato & $88-108$ & $16-32$ & $34-86$ \\
\hline
\end{tabular}




\section{AGRICULTURAL AND FOOD SCIENCE}

I. Keres et al. (2020) 29: 210-221

The tillage method in all treatments was mouldboard ploughing to a depth of $20-23 \mathrm{~cm}$. The conventional systems were treated with several synthetic pesticides against weeds, diseases and pests one to four times during growth as required. In the organic systems, weed control after sowing and in the winter wheat field at the end of April was carried out by spring tine harrowing. The cultivars used in this trial were mostly local cultivars bred at the Estonian Plant Breeding Institute: the potato cultivars Reet (2008-2010) and Maret (2011-2017), the barley cultivars Leeni (2008-2010) and Anni (2011-2017), the red clover cultivars Jõgeva 205 (2008-2011) and Varte (2012-2017). The foreign varieties used: winter wheat cultivars Portal (2008-2010), Olivin (2011) and Fredis (2012-2017), the pea cultivars Madonna (2008-2010) and Tudor (2011-2017). Those varieties are popular among Estonian farmers. In all treatments, the red clover was cut and ploughed into the soil in mid to late August.

Above-ground biomass samples of the red clover crop were taken from a sample size of $1 \mathrm{~m}^{2}$ before harvest. Winter wheat, barley and pea were harvested with a Sampo harvester with header width of $2 \mathrm{~m}$, i.e. the test area for grain yield calculation was $20 \mathrm{~m}^{2}$. The samples were dried for $48 \mathrm{~h}$ at $105^{\circ} \mathrm{C}$ for biomass DM measurement. Potato DM measurements are previously described (Tein et al. 2014).

\section{Chemical analyses}

Once a year in mid-April before the start of field operations, soil samples were taken from each plot to a depth of 0-23 cm. Eight samples were taken from each plot and combined to provide one composite sample for analysis. Soil $\mathrm{pH}$ was determined on $2 \mathrm{~mm}$ sieved, air dry samples in $1 \mathrm{M} \mathrm{KCl} \mathrm{1:2.5.} \mathrm{Acid} \mathrm{digestion} \mathrm{by} \mathrm{sulphuric} \mathrm{acid} \mathrm{solution}$ was used to determine $P_{\text {tot }}$ and $\mathrm{K}_{\text {tot }}$ concentrations of cattle manure and plant samples. Total nitrogen $\left(\mathrm{N}_{\text {tot }}\right)$ content of oven-dried well composted manure samples was determined by dry combustion method on a varioMAX CNS elemental analyzer (ELEMENTAR, Germany) (Methods of Soil and Plant Analysis 1986). Plant available P and $\mathrm{K}$ concentrations in the soil samples were determined by the ammonium lactate (AL) method (Egnér et al. 1960).

The $\mathrm{P}$ and $\mathrm{K}$ amount ploughed into the soil with cover crop biomass ( $\mathrm{P}$ and $\mathrm{K}$ input into the soil) was calculated using total $\mathrm{P}$ and $\mathrm{K}$ uptake by cover crops ( $\mathrm{P}$ or $\mathrm{K}$ concentration multiplied by above-ground biomass DM yield).

\section{Calculation of total yield per treatment}

The number of indicators used in statistical analysis was 280 for each crop ( 7 treatments $\times 4$ replication $\times 10$ years).

Total yield was calculated as the sum of the DM yields of organic and conventional crops in each fertiliser treatment (i.e. 5 crops $\times 1$ treatment $\times 4$ replication):

$$
\text { Total } Y(1 . .7)=G Y_{\text {barley }(1 . .7)}+\text { Biom } Y_{\text {clover }(1 . .7)}+G Y_{w w(1 . .7)}+G Y_{\text {pea }(1 . .7)}+T Y_{\text {potato(1..7) }}
$$

where (1...7) = fertilising treatments Org 0(1), Org I(2), Org II(3), NO(4), N1(5), N2(6), N3(7), respectively; GY $\mathrm{GY}_{\mathrm{ww}(1.7)^{\prime}} \mathrm{GY}_{\text {pea(1..7) }}=$ grain yield of barley, winter wheat and pea for respective fertilising treatment; BiomY $\mathrm{P}_{\text {clover(1.7) }}=$ biomass yield of red clover crop for respective fertilising treatment; $\mathrm{TY}_{\text {potato(1..7) }}=$ tuber yield of potato for respective fertilising treatment.

Total DM yield of fertilising treatment as an average of 10 years for each fertilising treatment was calculated as follows:

$$
\text { Annual total } Y(1 . .7)=\frac{\text { Total } Y_{2008(1 . .7)}+\ldots+\text { Total } Y_{2017(1 . .7)}}{10}
$$

where Total $Y_{2008(1.7)}=$ total yield of five field crops in respective treatment in 2008. Total yield (the sum of the DM yields of the five crops receiving the same fertiliser treatment) was calculated for each year (i.e. Total $\left.Y_{2008 . .2017}\right)$. Total database for statistical analysis was $n=1400$ ( 5 crops $\times 7$ treatments $\times 4$ replication $\times 10$ years).

\section{Calculation of PK-balance}

The plant available $\mathrm{P}$ and $\mathrm{K}$ amounts immobilised by winter cover crops and red clover biomass were not taken into account in calculation of input/output balance of $\mathrm{P}$ and $\mathrm{K}$ as they did not add any PK into the system and were ploughed back into the soil. 
Annual $P, K$ balance $($ Org 0, OrgI,$N 0)=0-\left(\frac{P, \text { Kbarley }}{10}+\frac{P, \mathrm{Kww}}{10}+\frac{P, \text { Kpea }}{10}+\frac{P, K p o t}{10}\right.$

Annual $P, K$ balance $($ OrgII $)=\frac{P m, K m}{10}-\left(\frac{P, \text { Kbarley }}{10}+\frac{P, \mathrm{Kww}}{10}+\frac{P, \text { Kpea }}{10}+\frac{P, \text { Kpotato }}{10}\right) / 4$

Annual $P, K$ balance $($ conv $)=(P$, Krate $)-\left(\frac{\text { Pbarley }}{10}+\frac{\text { Pww }}{10}+\frac{\text { Ppea }}{10}+\frac{\text { Ppotato }}{10}\right) / 4$

where $\mathrm{P}_{\mathrm{m}^{\prime}}, \mathrm{K}_{\mathrm{m}}=$ input of $\mathrm{P}$ and $\mathrm{K}$ with cattle manure; $\left(\frac{P, \text { Kbarley }}{10}+\frac{\mathrm{P}, \mathrm{Kww}}{10}+\frac{P, \text { Kpea }}{10}+\frac{P, \text { Kpotato }}{10}\right) / 4=$ mean

output of $\mathrm{P}$ and $\mathrm{K}$ over 4 crops (barley, winter wheat, pea and potato, respectively) as an average of ten years; conv $=\mathrm{P}, \mathrm{K}$ balance in the soil of conventional treatments; $\mathrm{P}, \mathrm{K}$ rate $=$ annually applied mineral $\mathrm{P}$ and $\mathrm{K}$ in conventional treatments (25 and $95 \mathrm{~kg} \mathrm{ha}^{-1}$, respectively).

\section{Weather conditions}

The climate of Estonia is slightly continental at the experimental site. The winter period (average air temperature permanently below $0{ }^{\circ} \mathrm{C}$ ) lasts on average 115 days with an average mean temperature of the coldest months of $-5.5^{\circ} \mathrm{C}$. The average duration of the vegetation period (air temperature permanently above $5^{\circ} \mathrm{C}$ ) is $175-190$ days. The average period without night frosts is four months, during which time the average midsummer (July) temperature is $16-17^{\circ} \mathrm{C}$. Mean annual precipitation is $550-700 \mathrm{~mm}$; the average precipitation in the wettest months (April to the end of October) is $350-500 \mathrm{~mm}$ (Keppart and Loodla 2006).

Meteorological data were collected from a meteorological station approximately $2 \mathrm{~km}$ from the trial site (Tables 2 and 3). The effect of weather on yields is discussed in more detail in the results section.

Table 2. Mean temperature $\left({ }^{\circ} \mathrm{C}\right)$ in 2008-2017 compared with the long-term average (1969-2017) data

\begin{tabular}{|c|c|c|c|c|c|c|c|c|c|c|c|}
\hline \multirow{2}{*}{ Month } & \multicolumn{10}{|c|}{ Trial years } & \multirow{2}{*}{$\begin{array}{c}\text { Long-term } \\
\text { average } \\
\text { 1969-2017 }\end{array}$} \\
\hline & 2008 & 2009 & 2010 & 2011 & 2012 & 2013 & 2014 & 2015 & 2016 & 2017 & \\
\hline January & $-1.3^{*}$ & -3.4 & -12.6 & $-4,8$ & -6.1 & -7.3 & -8.1 & -1.9 & -9.2 & -3.4 & -5.3 \\
\hline February & 0.6 & -4.8 & -7.4 & -10.7 & -11.5 & -3.3 & -0.3 & -1.0 & 0.3 & -2.9 & -5.5 \\
\hline March & 0.4 & -1.5 & -2.1 & -1.9 & -0.3 & -7.8 & 2.2 & 2.6 & 0.0 & 1.4 & -1.5 \\
\hline April & 7.2 & 5.3 & 6.1 & 6.4 & 5.0 & 3.5 & 6.5 & 5.4 & 6.1 & 3.4 & 5.0 \\
\hline May & 10.6 & 11.4 & 12.6 & 11.0 & 11.8 & 14.8 & 11.9 & 10.3 & 14.0 & 10.3 & 11.5 \\
\hline June & 14.5 & 13.8 & 14.6 & 17.2 & 13.6 & 18.2 & 13.4 & 14.2 & 15.9 & 14.0 & 15.3 \\
\hline July & 16.1 & 16.9 & 22.2 & 19.9 & 17.9 & 17.7 & 19.3 & 15.7 & 17.8 & 15.9 & 17.6 \\
\hline August & 15.8 & 15.4 & 18.4 & 15.8 & 15.2 & 17.0 & 16.8 & 17.0 & 16.1 & 16.8 & 16.2 \\
\hline September & 9.8 & 12.8 & 11.1 & 12.3 & 12.2 & 10.8 & 12.1 & 12.6 & 12.3 & 12.2 & 11.1 \\
\hline October & 8.2 & 4.1 & 4.2 & 6.8 & 5.7 & 6.6 & 5.2 & 4.6 & 4.1 & 5.2 & 5.6 \\
\hline November & 2.3 & 2.3 & 0.3 & 2.9 & 2.6 & 3.5 & 1.4 & 3.6 & -1.0 & 2.4 & 0.6 \\
\hline December & -1.1 & -5.5 & -8.2 & 1.0 & -6.8 & 1.1 & -1.6 & 2.4 & -0.3 & 0.2 & -2.9 \\
\hline Average of year & 6.9 & 5.6 & 4.9 & 6.3 & 5.0 & 6.2 & 6.6 & 7.2 & 6.3 & 6.3 & 5.6 \\
\hline
\end{tabular}




\begin{tabular}{|c|c|c|c|c|c|c|c|c|c|c|c|}
\hline \multirow{2}{*}{ Month } & \multicolumn{10}{|c|}{ Trial years } & \multirow{2}{*}{$\begin{array}{l}\text { Long-term } \\
\text { average } \\
\text { 1969-2017 }\end{array}$} \\
\hline & 2008 & 2009 & 2010 & 2011 & 2012 & 2013 & 2014 & 2015 & 2016 & 2017 & \\
\hline February & 34 & 7 & 12 & 9 & 19 & 14 & 12 & 8 & 56 & 22 & 23 \\
\hline March & 8 & 22 & 30 & 6 & 39 & 16 & 9 & 12 & 23 & 17 & 22 \\
\hline May & 27 & 13 & 61 & 58 & 82 & 61 & 84 & 62 & 2 & 15 & 54 \\
\hline June & 111 & 137 & 73 & 35 & 101 & 52 & 103 & 39 & 125 & 94 & 77 \\
\hline July & 54 & 55 & 36 & 48 & 75 & 63 & 71 & 61 & 82 & 61 & 69 \\
\hline October & 68 & 116 & 49 & 48 & 45 & 45 & 36 & 11 & 33 & 75 & 56 \\
\hline November & 49 & 36 & 78 & 34 & 50 & 70 & 10 & 54 & 46 & 26 & 45 \\
\hline December & 24 & 57 & 18 & 53 & 9 & 47 & 42 & 46 & 31 & 52 & 37 \\
\hline SUM $\Sigma$ & 588 & 605 & 586 & 456 & 639 & 510 & 540 & 492 & 539 & 629 & 585 \\
\hline
\end{tabular}

*data from Eerika meteorological station

\section{Statistical analyses.}

Correlation, factorial analyses of variance (ANOVA) and two-factor ANOVA were used to test the effect of farming systems and climatic conditions on each crop's DM yield. Descriptive analysis and Fisher's least significant difference test for homogenous groups were used for testing significance differences between farming systems, experimental year and crop mean DM yields. The means are presented with their standard errors $( \pm S E)$ (bars in the figures). The level of statistical significance was set at $p<0.05$ if not indicated otherwise.

\section{Results}

\section{Total yield and amount of $\mathrm{P}$ and $\mathrm{K}$ removed in different farming systems}

The total yield of the five crops fertilized similarly was significantly influenced by farming system $(p<0.001$, Fig. 1$)$ and weather conditions ( $p<0.001$, Fig 2 ). The proportion of variation for farming system and weather conditions was quite similar, $47 \%$ and $43 \%$, respectively. The total yield of crops as an average of trial years in the organic treatments ranged between 21.5-22.4 $\mathrm{t} \mathrm{ha}^{-1}$ compared with 29.0-29.8 $\mathrm{t} \mathrm{ha}^{-1}$ in the conventional system (Fig. 1). Differences between the treatments within each system were not significant, except conventional 0 , which was similar to organic treatments. Total yields of organic treatments were 3-28\% lower than those of conventional treatments.

Over the ten years, the total yield of the five crops averaged across treatments ranged between $20.3-31.5 \mathrm{t} \mathrm{ha}^{-1}$ (Fig. 2). A 19-27\% higher total yield of crops was obtained in 2009, 2012 and 2017, caused mostly by an increase in potato and winter wheat yields. Our results showed that temperature in April and September was important in terms of total yield formation (Table 3). A $1.4-2.2^{\circ} \mathrm{C}$ higher temperature than the long-term average in April resulted in 9-72\% lower yield level of winter wheat $(r=-0.42, p<0.01, n=70)$ while a temperature $2.3-2.8^{\circ} \mathrm{C}$ higher than the long-term average in September resulted in $26-57 \%$ higher yield level of potato $(r=0.47, p<0.001, n=70)$. A higher potato tuber yield was obtained in years when the mean temperature in September was higher than the long-term average. The influence of precipitation on total crop yield was not significant, but the distribution of precipitation was very important. In 2015 the sum of precipitation per year was $93 \mathrm{~mm}$ lower than that of the longterm average, but the total yield of the five crops was not different from the record yields in 2009, 2012 and 2017. 

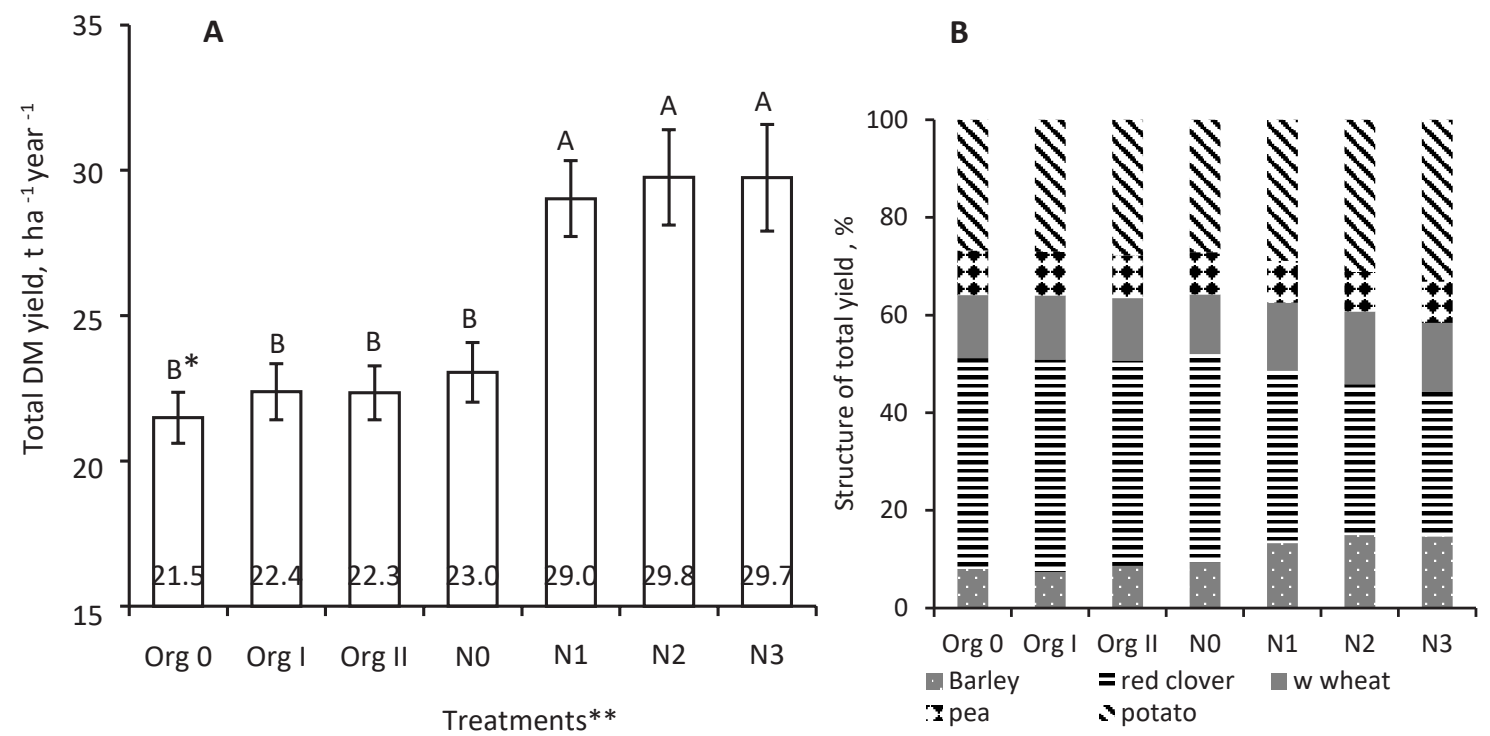

Fig. 1. Annual total yield of five crops (t ha ${ }^{-1}$ per year) in different treatments (A). Composition (\%) of total yield of five crops in different treatments $(B) . F_{(6,63)}=9.271, p<0.001$. * The means marked with the same letter do not differ statistically significantly from each other; ** Org0 and $\mathrm{NO}=$ control treatments of organic and conventional farming, respectively; Orgl = organic treatment with winter cover crops CC; OrgII = additionally to CC the well composted cattle manure applied; N1 = amounts of mineral NPK per ha: 40-50 kg N, $25 \mathrm{~kg} \mathrm{P,} 95 \mathrm{~kg} \mathrm{~K}$; N2 = amounts of mineral NPK per ha: 80-100 kg N, $25 \mathrm{~kg}$ P, $95 \mathrm{~kg}$ K; N3 = amounts of mineral NPK per ha: 120-150 kg N, 25 kg P, 95 kg K. Less mineral N fertilisers were applied to barley undersown with red clover.

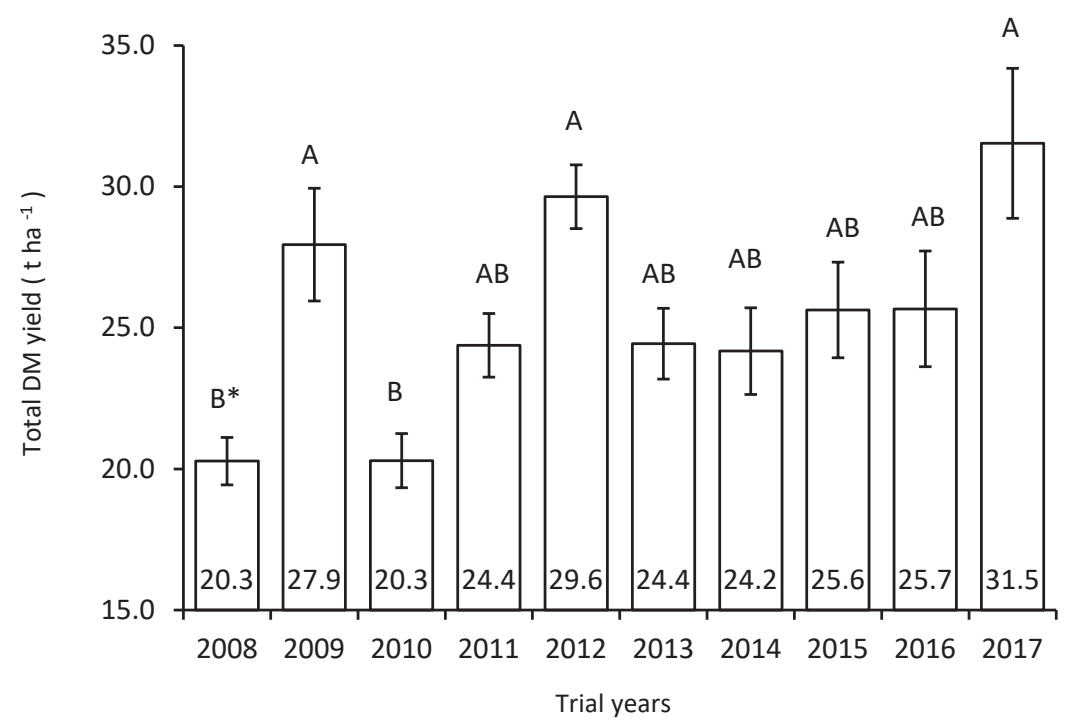

Fig. 2. Total yield of five crops $\left(\mathrm{t} \mathrm{ha}^{-1}\right)$ in different trial years as an average of treatments. *the means marked with the same letter do not differ statistically significantly from each other

The amount of $\mathrm{P}$ and $\mathrm{K}$ removed from the field depended on crop yield in both organic and conventional treatments. Annual amounts of $\mathrm{P}$ removed with field crops in all organic treatments did not differ statistically from the control treatment of the conventional system (variation between 11.4-11.9 kg ha-1); annual amounts of $P$ removed from fertilised treatments of the conventional system were $28-35 \%$ higher. The same data for annually $\mathrm{K}$ removal were $42.0-44.2 \mathrm{~kg} \mathrm{ha}^{-1}$, which was $28-40 \%$ higher than that of the organic treatments.

\section{Soil $\mathrm{pH}$ in the organic and conventional systems}

The soil $\mathrm{pH}$ was significantly influenced by farming system ( $r=0.31, p<0.001)$ and weather conditions $(r=0.07, p<0.01)$; the proportion of variation for farming treatments and weather conditions were $14 \%$ and $5 \%$, respectively (Fig. 3 ). 


\section{AGRICULTURAL AND FOOD SCIENCE}

I. Keres et al. (2020) 29: 210-221

Descriptive analysis showed that at the beginning of the field trial the $\mathrm{pH}$ values of all treatments did not differ statistically; mean $\mathrm{pH}$ values in organic and conventional treatments were $5.93 \pm 0.03$ and $5.82 \pm 0.03$, respectively. After 10 years of field experiment the $\mathrm{pH}$ values in organic treatments had increased by 0.24 units on average $(\mathrm{pH}$ values ranged between 5.9-6.3) after fertilisation with cattle manure. The soil pH values of conventional treatments had decreased by 0.23 units on average ( $\mathrm{pH}$ value ranged between 5.4-5.9).

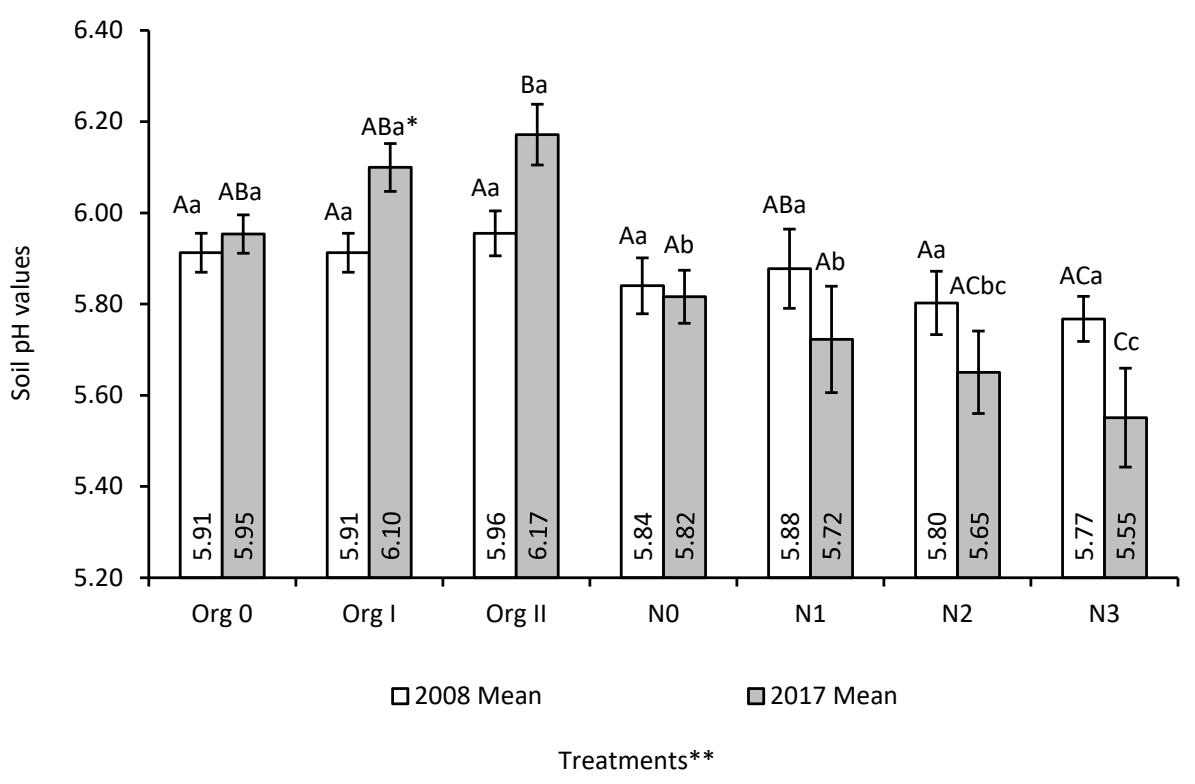

Fig. 3. Soil $\mathrm{pH}$ values under different treatments at the beginning of the field experiment and after ten years. 2008 Mean: $\mathrm{F}_{(6,133)}=1.268, p=0.276 ; 2017$ Mean: $\mathrm{F}_{(6,133)}=8.215, p<0.001$; *different upper case letters indicate a significant difference between years, and different lower case letters indicate the difference between treatments in a given year; ${ }^{*}$ *See explanations under Figure 1

\section{PAL and KAL contents in the soil $\left(\mathrm{mg} \mathrm{kg}^{-1}\right)$ after long-term organic and conventional farming}

The correlation analysis showed that plant available $\mathrm{P}$ in the soil of organic treatments declined significantly after ten years $(r=-0.19, p<0.001)$. At the beginning of the experiment it did not differ significantly between the farming system treatments (variation was $90.7-118.7 \mathrm{mg} \mathrm{P} \mathrm{kg}^{-1}$ soil-1). However, by descriptive analysis plant available $P$ had decreased in all organic treatments after 10 years and in the control treatment of conventional farming by 18.9-23.6 mg P kg-1 soil-1 (Fig. 4); after 10 years the $P$ content of fertilised treatments of the conventional farming system did not differed statistically from the data from the beginning of the field trial.

The plant available $\mathrm{K}$ in soil decreased over ten years in all treatments $(r=0.88, p<0.001)$. At the beginning of the experiment there was no statistical difference between the two farming system treatments (variation was 160.7$174.4 \mathrm{mg} \mathrm{K} \mathrm{kg}^{-1}$ soil $^{-1}$, Fig. 5). After ten years the greatest decrease in $\mathrm{K}$ content was in control variants of both farming systems $\left(60 \mathrm{mg} \mathrm{K} \mathrm{kg}^{-1}\right.$ soil $\left.^{-1}\right)$, followed by Org I and Org II. The amount of available $\mathrm{K}$ in the soil decreased less in the fertilised conventional treatments (17.1-39.5 $\mathrm{mg} \mathrm{K} \mathrm{kg}^{-1}$ soil-1, see chapter Discussion).

\section{PK-balance in the soil of different treatments}

Since cover crops and red clover biomass and straw of other crops were not removed from the field, the values of these data were not accounted for in the balance calculation of soil $\mathrm{P}$ and $\mathrm{K}$ (Table 4 and 5). 


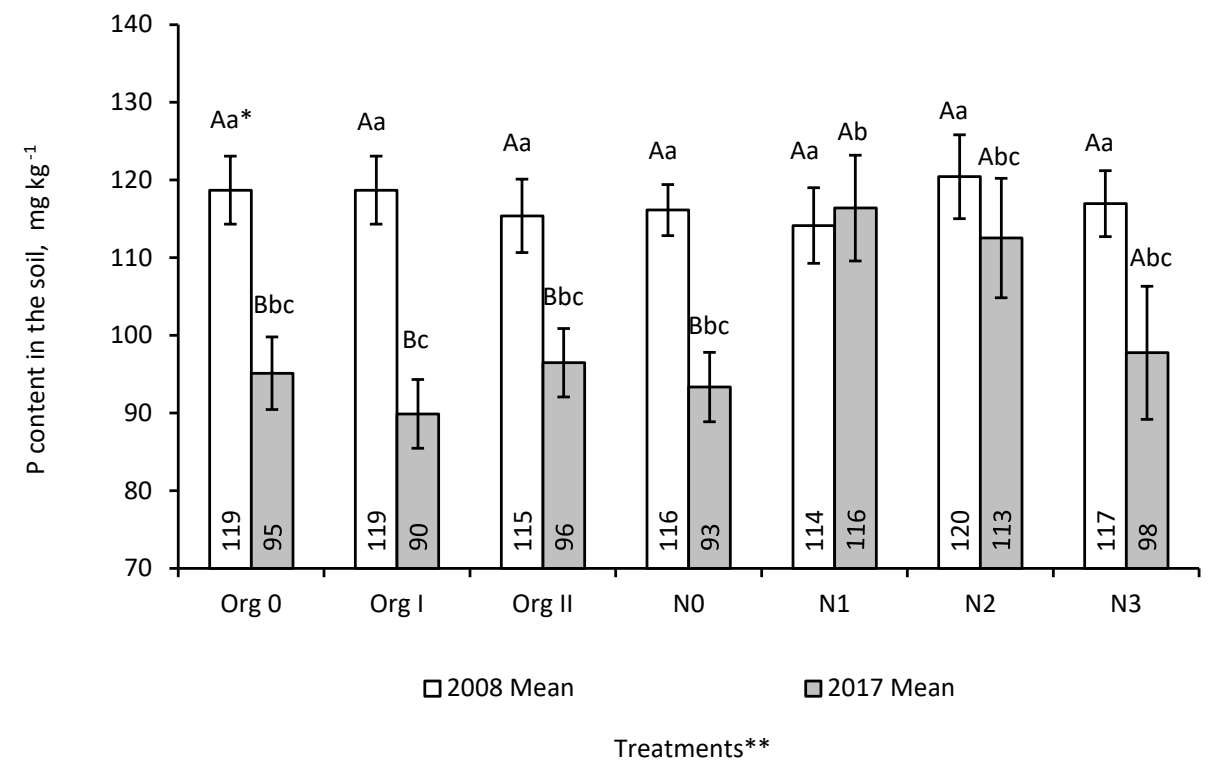

Fig. 4. Plant available $P$ content $\left(\mathrm{mg} \mathrm{kg}^{-1}\right)$ in the soil at the beginning of the field trial and after ten years. 2008 Mean: $F_{(6,133)}=1.268, p=0.276 ; 2017$ Mean: $F_{(6,133)}=2.754, p=0.0149$; *different large letters indicate a significant difference between years, and different small letters indicate the difference between treatments in a given year; **See explanations under Figure 1

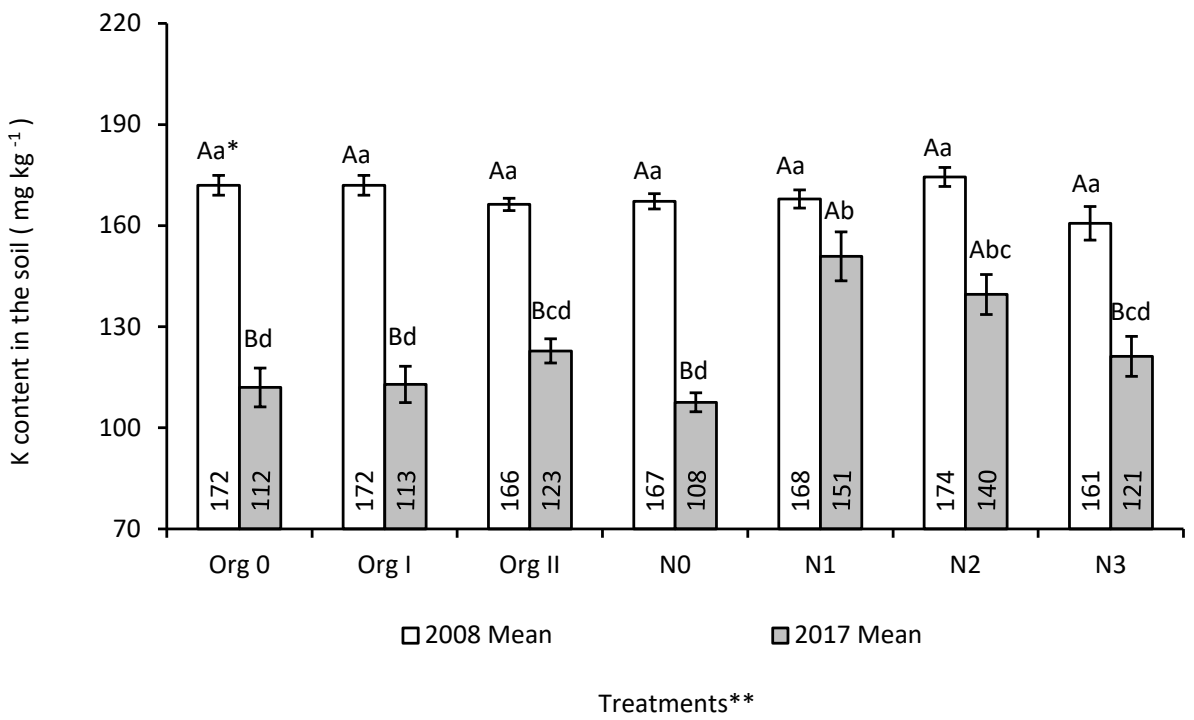

Fig. 5. Plant available $\mathrm{K}$ content $\left(\mathrm{mg} \mathrm{kg}^{-1}\right)$ in the soil at the beginning of the field trial and after ten years. 2008 Mean: $F_{(6,133)}=1.268, p=0.276 ; 2017$ Mean: $F_{(6,133)}=8.215, p<0.001$; *different large letters indicate a significant difference between years, and different small letters indicate the difference between treatments in a given year; ** See explanations under Figure 1

The calculated input/output balance of $\mathrm{P}$ and $\mathrm{K}$ was quite different in the organic and the conventional system. The $P$ balance showed that in the organic system the cultivation of winter cover crops did not decrease the annual loss of $P$, whereas the application of cattle manure decreased the loss of $P$ by $9 \mathrm{~kg} \mathrm{ha}^{-1}$ compared with control treatment Org 0 (Table 4). The $\mathrm{K}$ balance showed that in the organic system all treatments had a negative balance (Table 5). Only the cattle manure application decreased the annual loss of $\mathrm{K}$ by $29.3 \mathrm{~kg} \mathrm{ha}^{-1}$ compared with control treatment Org 0 . In the conventional system the calculated balance of $\mathrm{P}$ and $\mathrm{K}$ was positive in all fertilised treatments (Table 4 and 5). The input/output balance in both control treatments for $\mathrm{P}$ and $\mathrm{K}$ amounts was the most negative, whereas the decrease of these elements was higher in the control treatment of the conventional system because of use of pesticides and up to $7 \%$ higher total yield level. Most of the plant available P and $\mathrm{K}$ was 
I. Keres et al. (2020) 29: 210-221

removed by the potato crop each year, which was also expected because of the much higher yield of tubers. $\mathrm{P}$ and $\mathrm{K}$ removed by the potato crop were up to 1.8 and 10.2 times higher than removal by other crops, respectively.

Table 4. Mean amount of $\mathrm{P}\left(\mathrm{kg} \mathrm{ha}^{-1}\right)$ annually applied and removed by different crop yields from different treatments and input/ output balance in the soil as an average of ten years

\begin{tabular}{|c|c|c|c|c|c|c|c|}
\hline \multirow[b]{2}{*}{ Treatment } & \multirow[b]{2}{*}{ Input kg ha-1 } & \multicolumn{4}{|c|}{ P output kg ha ${ }^{-1}$} & \multirow{2}{*}{$\begin{array}{l}\text { Mean output } \\
\text { across } \\
\text { crops* }\end{array}$} & \multirow{2}{*}{$\begin{array}{l}\text { Input - } \\
\text { output }\end{array}$} \\
\hline & & $\begin{array}{l}\text { Barley + red } \\
\text { clover }\end{array}$ & $\begin{array}{l}\text { Winter } \\
\text { wheat }\end{array}$ & Pea & Potato & & \\
\hline \multicolumn{8}{|l|}{ Organic } \\
\hline Org 0 & & $6.9 \pm 0.3$ & $12.2 \pm 0.6$ & $9.9 \pm 0.6$ & $15.6 \pm 1.2$ & $11 \pm 1.8 \mathrm{~b}$ & -11.2 \\
\hline Org 1 & 0 & $7.0 \pm 0.3$ & $13.2 \pm 0.9$ & $10.6 \pm 0.6$ & $16.0 \pm 1.1$ & $12 \pm 1.9 \mathrm{~b}$ & -12.2 \\
\hline Org II & $10.0 \pm 2.5$ & $7.9 \pm 0.5$ & $12.2 \pm 0.9$ & $9.5 \pm 0.6$ & $16.2 \pm 1.0$ & $12 \pm 1.8 \mathrm{~b}$ & -2.2 \\
\hline \multicolumn{8}{|l|}{ Conventional } \\
\hline NO & 0 & $8.5 \pm 0.5$ & $11.5 \pm 0.8$ & $9.8 \pm 0.7$ & $17.9 \pm 1.4$ & $12 \pm 2.1 \mathrm{~b}$ & -11.9 \\
\hline N1 & 25 & $14.9 \pm 0.9$ & $17.8 \pm 1.1$ & $11.7 \pm 0.7$ & $21.5 \pm 1.2$ & $17 \pm 2.1 \mathrm{a}$ & 8.5 \\
\hline N2 & 25 & $16.6 \pm 0.9$ & $19.1 \pm 1.0$ & $11.3 \pm 0.7$ & $22.9 \pm 1.4$ & $18 \pm 2.4 \mathrm{a}$ & 7.5 \\
\hline N3 & 25 & $16.0 \pm 0.9$ & $17.9 \pm 1.2$ & $11.6 \pm 0.9$ & $24.5 \pm 1.7$ & $18 \pm 2.7 \mathrm{a}$ & 7.5 \\
\hline $\begin{array}{l}\text { Mean over } \\
\text { treatments }\end{array}$ & & $11 \pm 1.7 c^{*}$ & $15 \pm 1.2 b$ & $11 \pm 0.3 \mathrm{c}$ & $19 \pm 1.4 \mathrm{a}$ & $14.0 \pm 1.1$ & \\
\hline
\end{tabular}

*the means marked with the same letter do not differ statistically significantly from each other

Table 5. Mean amount of $\mathrm{K}\left(\mathrm{kg} \mathrm{ha}^{-1}\right)$ applied and removed by different crop yields from different treatments annually and input/ output balance in the soil as an average of ten years

\begin{tabular}{|c|c|c|c|c|c|c|c|}
\hline \multirow[b]{2}{*}{ Treatment } & \multirow[b]{2}{*}{ Input kg ha ${ }^{-1}$} & \multicolumn{4}{|c|}{ K output kg ha ${ }^{-1}$} & \multirow{2}{*}{$\begin{array}{c}\text { Mean output } \\
\text { across } \\
\text { crops* }\end{array}$} & \multirow{2}{*}{$\begin{array}{l}\text { Input - } \\
\text { output }\end{array}$} \\
\hline & & $\begin{array}{l}\text { Barley + } \\
\text { red clover }\end{array}$ & $\begin{array}{l}\text { Winter } \\
\text { wheat }\end{array}$ & Pea & Potato & & \\
\hline \multicolumn{8}{|c|}{ Organic } \\
\hline Org 0 & 0 & $9.1 \pm 0.5$ & $12.8 \pm 0.7$ & $20.2 \pm 1.0$ & $121 \pm 7.0$ & $41 \pm 26.8 a$ & -40.8 \\
\hline Org 1 & 0 & $9.3 \pm 0.5$ & $13.7 \pm 0.9$ & $20.8 \pm 1.1$ & $126 \pm 7.0$ & $43 \pm 28.0 a$ & -43.9 \\
\hline Org II & $32.1 \pm 4.4$ & $10.6 \pm 0.7$ & $13.0 \pm 0.9$ & $19.7 \pm 1.0$ & $131 \pm 5.8$ & $44 \pm 29.2 a$ & -11.5 \\
\hline \multicolumn{8}{|c|}{ Conventional } \\
\hline NO & 0 & $11.8 \pm 0.6$ & $12.8 \pm 1.0$ & $20.2 \pm 1.3$ & $135 \pm 7.7$ & $45 \pm 30.1 a$ & -45.0 \\
\hline N1 & 95 & $21.3 \pm 1.0$ & $20.2 \pm 1.4$ & $26.6 \pm 1.2$ & $180 \pm 7.3$ & $62 \pm 39.3 a$ & 33 \\
\hline N2 & 95 & $22.6 \pm 1.0$ & $21.8 \pm 1.2$ & $25.3 \pm 1.2$ & $194 \pm 8.9$ & $66 \pm 42.7 a$ & 29.1 \\
\hline N3 & 95 & $23.0 \pm 0.9$ & $20.5 \pm 1.4$ & $33.8 \pm 6.2$ & $215 \pm 12.2$ & $73 \pm 47.4 a$ & 21.9 \\
\hline $\begin{array}{l}\text { Mean over } \\
\text { treatments }\end{array}$ & & $15 \pm 2.5 c^{*}$ & $16 \pm 1.6 \mathrm{c}$ & $24 \pm 2.0 b$ & $157 \pm 14.4 a$ & $53 \pm 19.9$ & \\
\hline
\end{tabular}

*the means marked with the same letter do not differ statistically significantly from each other.

\section{Discussion}

The purpose of this experiment was to compare the effectiveness of long-term use of composted manure and winter cover crops and the use of mineral fertilisers (with different $\mathrm{N}$ norms) on the maintenance of soil fertility in a five course crop rotation, with a high requirement for nutrients. This article discusses the changes in soil $P$ and $\mathrm{K}$ content and $\mathrm{pH}$ values during 10 years. Káš et al. (2016) found that long-term fertilisation with mineral and organic fertilisers affected yields and overall export of nutrients from the field and brought about many changes in the soil. After 10 years of mineral fertiliser use in the conventional farming system, the soil became more acidic in all treatments, i.e. the $\mathrm{pH}$ values decreased up to 0.5 units. In Estonian climatic conditions, where precipitation exceeds evaporation, many soil types are characterized by acidification over time (Järvan and Vettik 2016). After 10 years of cattle manure use in the organic farming system, soil pH became less acidic, which was expected, because the $\mathrm{pH}$ values of applied cattle manure ranged between 6.6-8.3. Gosling and Shepherd (2005) and Kirchmann et al. (2007) found that organic cropping systems, which rely heavily on legumes in the rotation, will acidify soils faster than systems with less legumes in the rotation. Our five field-crop rotation includes only two legume crops (red clover and field pea). Watson et al. (2002) reported that higher amounts of organic fertilisers in organic farming systems have increased soil microbial biomass and activity but have not necessarily ensured higher yields. 


\section{AGRICULTURAL AND FOOD SCIENCE}

I. Keres et al. (2020) 29: 210-221

The availability of $\mathrm{N}$ in the early stages of plant development is very important in terms of crop formation and yield level. Earlier results of our long-term field experiment showed that $\mathrm{N}$ limited the yield level in organic system, and two legumes, winter cover crops and manure in the five-field crop rotation did not meet the $\mathrm{N}$ requirements of crops, because it was not always in line with $\mathrm{N}$ availability (Alaru et al. 2014). More nutrients are removed from the soil with higher yields. In this field trial the annual amounts of $\mathrm{P}$ and $\mathrm{K}$ removed in conventionally fertilised treatments were $28-35 \%$ and $28-40 \%$, respectively, higher than in organic treatments because of $24-25 \%$ higher yields. Mineral $\mathrm{N}$ fertilisation caused a significant increase of overall $\mathrm{P}$ and $\mathrm{K}$ uptake in experimental plots, which is consistent with Káš et al. (2016). This can lead to a decrease of nutrient reserve in soils (Bhattacharyya et al. 2015). During 10 years experimentation the amounts of $P$ and $K$ in the organic farming system decreased by up to $24 \mathrm{mg}$ and $60 \mathrm{mg} \mathrm{kg}^{-1}$ soil $^{-1}$, respectively. Although $\mathrm{P}$ and $\mathrm{K}$ outputs were smaller in the organic system due to lower yields, the use of organic fertilisers did not prevent the decrease of plant available $\mathrm{P}$ and $\mathrm{K}$ amounts in the soil. The highest annual uptake of $\mathrm{P}$ and $\mathrm{K}$ from soil was by the potato crop, followed by winter wheat; the amount of $\mathrm{P}$ and $\mathrm{K}$ removed with potato yield was $35 \%$ and $74 \%$, respectively, from the total annually removed $\mathrm{P}$ and $\mathrm{K}$ in this crop rotation experiment. Srinivasarao and Srinivas (2017) reported that tuber crops can remove as much as $1000 \mathrm{~kg} \mathrm{~K} \mathrm{ha}^{-1}$. The choice of crops for crop rotation is very important to preserve soil fertility. In our field experiment the replacement of potato by another crop would be conducive to less negative $\mathrm{K}$ balance (for example by buckwheat). If soil fertility deteriorates, crop rotation should be reviewed at certain intervals.

Nutrient budgeting on organic farms often shows a deficit of P and K (Gosling and Shepherd 2005, Kirchmann et al. 2007). The input/output balance of $P$ and $K$ was negative in all treatments of the organic system.

$\mathrm{P}$ and $\mathrm{K}$ balances showed that in the conventional system the soil of all fertilised variants should have had sufficient amounts of $\mathrm{P}$ and $\mathrm{K}$, while actual $\mathrm{K}$ data of soil did not confirm this. Our results showed that over the 10 year trial period plant available $\mathrm{K}$ content in the conventional treatments decreased up to $40 \mathrm{mg} \mathrm{K} \mathrm{kg}^{-1} \mathrm{soil}$ (Fig. 5). Yadav et al. (2000) found that despite annual $\mathrm{K}$ additions, at recommended rates through fertilisers, available $\mathrm{K}$ content decreased due to continuous cropping. Such a contradiction in results may be due to the fact that part of the $\mathrm{K}$ given to the plants with fertilisers was chemically immobilised by soil particles or leached and consequently the amounts of plant available K were reduced (Srinivasarao and Srinivas 2017). The input/output balance for $P$ showed that $P$ content in the fertilised treatments of the conventional system should have increased annually by $7.5-8.5 \mathrm{~kg} \mathrm{ha}^{-1}$, but the actual results showed that after 10 years the plant available $P$ content was statistically the same as at the beginning (Fig. 4). In Estonian mineral soils, $\mathrm{P}$ is a particularly problematic element because, given the $\mathrm{pH}$ of our soils, the range of optimal response to $\mathrm{P}$ absorption is narrow (Roostalu 2012). According to Berry et al. (2003) the budget deficit of $P$ is small when it is $<10 \mathrm{~kg} \mathrm{ha}^{-1}$ per year; deficit of $\mathrm{K}$ is large when it exceeds 50 $\mathrm{kg} \mathrm{ha}^{-1}$ per year. In conditions of $\mathrm{K}$ shortage, crop plants draw from the soil reserve $\mathrm{K}$ to meet their nutritional requirements (Sardans and Penuelas 2015). At the beginning of our experiment the soil P fertiliser requirement was average and it did not change in 10 years, but the $\mathrm{K}$ fertiliser demand increased from medium to high.

Srinivasarao and Srinivas (2017) reported that because of heavy removal of nutrients from soil under multiple cropping systems with high yielding and fertiliser-responsive varieties, the $\mathrm{P}$ and $\mathrm{K}$ status of soils is changing rapidly. It is of great importance to keep a close watch on such depletion through regular monitoring to ensure that $P$ and $\mathrm{K}$ do not become limiting factors in crop production and to commence their application in appropriate doses so that deficiency does not occur.

\section{Conclusions}

This 10 year comparison between organic (winter cover crops and well composted manure) and conventional (mineral fertilisers) systems showed that: i) total yield of a five course crop rotation was $24-25 \%$ higher in conventionally fertilised treatments than in organic treatments; ii) the soil became more acidic in the conventional system due to the long-term use of mineral fertilisers, the use of liming may be a good solution to increase $\mathrm{pH}$; iii) during the 10 year conventional farming system experiment the plant available $\mathrm{P}$ content remained statistically unchanged and the $\mathrm{K}$ content decreased by up to $40 \mathrm{mg} \mathrm{K} \mathrm{kg}^{-1}$ soil-1. In the conventionally fertilised treatments the annual amounts of removed $\mathrm{P}$ and $\mathrm{K}$ were12-18 $\mathrm{kg} \mathrm{P} \mathrm{ha}^{-1}$ and $45-73 \mathrm{~kg} \mathrm{~K} \mathrm{ha}^{-1}$, which was respectively $28-$ $35 \%$ and $28-40 \%$ higher than in the organic treatments because of higher yields; iv) the use of winter cover crops and well composted cattle manure did not maintain the baseline levels of $\mathrm{P}$ and $\mathrm{K}$ in the soil, which require the greatest attention and must be viewed from the perspective of maintaining the soil fertility especially in organic system. In conclusion, to prevent the depletion of nutrient reserves in the soil, crop rotation should be changed from time to time. 


\section{Acknowledgments}

The study was supported by Estonian University of Life Sciences project 8-2/T13001PKTM, by Estonian Government Target Financing project SF170057s09, by institutional research funding IUT36-2 of the Estonian Ministry of Education and Research, by ERA-NET CORE-ORGANIC II project TILMAN - ORG and by ERA-NET CORE-ORGANIC Plus project FertilCrop. We are thankful to Prof. Christine Watson and Dr. James Holmes for linguistic guidance.

\section{References}

Alaru, M., Talgre, L., Eremeev, V., Tein, B., Luik, A., Nemvalts, A. \& Loit, E. 2014. Crop yields and supply of nitrogen compared in conventional and organic systems. Agricultural \& Food Science 23: 317-326. https://doi.org/10.23986/afsci.46422

Baldwin, K.R. 2006. Soil Fertility on Organic Farms. Organic Production. https://content.ces.ncsu.edu/soil-fertility-on-organicfarms/. Accessed 10 March 2019.

Berry, P.M., Stockdale, E.A., Sylvester-Bradley, R., Philipps, L., Smith, K.A., Lord, E.I., Watson, C.A. \& Fortume, S. 2003. N, P and K budgets for crop rotations on nine organic farmis in the UK. Soil Use and Management 19: 112-118.

https://doi.org/10.1079/SUM2003176

Bhattacharyya, P., Nayak, A.K., Shahid, M., Tripathi, R., Mohanty, S., Kumar, A., Raja, R., Panda, B.B., Lal, B., Gautam, P., Swain, C.K., Roy, K.S. \& Dash, P.K. 2015. Effects of 42-year long-term fertilizer management on soil phosphorus availability, fractionation, adsorption-desorption isotherm and plant uptake in flooded tropical rice. The Crop Journal 3: 387-395. https://doi.org/10.1016/j.cj.2015.03.009

Bulluck, L.R., Brosius, M., Evanylo, G.K. \& Ristaino, J.B. 2002. Organic and synthetic fertility amendments influence soil microbial, physical and chemical properties on organic and conventional farms. Applied Soil Ecology 19: 147-160. https://doi.org/10.1016/S0929-1393(01)00187-1

Deckers, J.A., Friessen, P., Nachtergaele, F.O.F. \& Spaargaren, O. 2002. World reference base for soil resources in a nutshell. In Micheli, E., Nachtergaele, F.O., Jones, R.J.A., Montanarella, L. (eds.). Soil Classification 2001. European Soil Bureau Research Report No. 7, EUR 20398 EN. p. 173-181.

Doltra, J. \& Olesen, J.E. 2013. The role of catch crops in the ecological intensification of spring cereals in organic farming under Nordic climate. European Journal of Agronomy 44: 98-108. https://doi.org/10.1016/j.eja.2012.03.006 https://doi.org/10.1016/j.eja.2012.03.006

Egner, H., Riehm, H. \& Domingo, W.R. 1960. Untersuchungen über die chemische Bodenanalyse als Grundlage für die Beurteilung des Nährstoffzustandes der Böden. II. Chemische Extraktionsmethoden zur Phosphor- und Kaliumbestimmung. Kungliga Lantbrukshögskolans Annaler 26: 199-215.

Esperschütz, J., Gattinger, A., Mäder, P., Schloter, M. \& Fliessbach, A. 2007. Response of soil microbial biomass and community structures to conventional and organic farming systems under identical crop rotations. FEMS Microbiology Ecology 61: $26-37$. https://doi.org/10.1111/j.1574-6941.2007.00318.x

EC 2014. Communication from the commission to the European Parliament, the Council, the European Economic and Social Committee and the Committee of the Regions. Action Plan for the future of Organic Production in the European Union Brussels, 24.3.2014 COM(2014) 179 final. www //organic-action-plan_en.pdf

Fliessbach, A., Mäder, P. \& Niggli, U. 2000. Mineralization and microbial assimilation of 14C-labeled straw in soils of organic and conventional agricultural systems. Soil Biology and Biochemistry 32: 1131-1139. https://doi.org/10.1016/S0038-0717(00)00028-6

García-Gil, J.C., Plaza, C., Soler-Rovira, P. \& Polo, A. 2000. Long-term effects of municipal solid waste compost application on soil enzyme activities and microbial biomass. Soil Biology and Biochemistry 32: 1907-1913. https://doi.org/10.1016/S00380717(00)00165-6

Gosling, P. \& Shepherd, M. 2005. Long-term changes in soil fertility in organic arable farming systems in England, with particular reference to phosphorus and potassium. Agriculture, Ecosystems and Environment 105: 425-432. https://doi.org/10.1016/j.agee.2004.03.007

Järvan, M. \& Vettik, R. 2016. Dynamics of plant nutrients in organically and conventionally managed soil extracted by different analyse methods. Journal of Agricultural Science XXVII: 55-64. (in Estonian).

Ju, X. \& Christie, P. 2011. Calculation of theoretical nitrogen rate for simple nitrogen recommendations in intensive cropping systems: A case study on the North China Plain. Field Crops Research 124: 450-458. https://doi.org/10.1016/j.fcr.2011.08.002

Káš, M., Mühlbachová, G., Kusá, H. \& Pechová, M. 2016. Soil phosphorus and potassium availability in long-term field experiments with organic and mineral fertilization. Plant, Soil and Environment 62: 558-565. https://doi.org/10.17221/534/2016-PSE

Keppart, L. \& Loodla, K. 2006. The potential of Estonian agro-climate and extraordinary weather situations during the last 50 years. http://www.cosis.net/abstracts/EMS2006/00422/EMS2006-A-00422.pdf. Accessed 10 May 2019.

Kirchmann, H., Bergström, L., Kätterer, T., Mattson, L. \& Gesslein, S. 2007. Comparison of long-term organic and conventional crop-livestock systems on a previosly nutrient-depleted soil in Sweden. Agronomy Journal 99: 960-972. https://doi.org/10.2134/agronj2006.0061

Kulhánek, M., Balík, J., Černý, J. \& Vaněk, V. 2009. Evaluation of phosphorus mobility in soil using different extraction methods. Plant, Soil and Environment 55: 267-272. https://doi.org/10.17221/43/2009-PSE

Li, X., Lu, J., Wu, L. \& Chen, F. 2009. The difference of potassium dynamics between yellowish red soil and yellow cinnamon soil under rapeseed (Brassica napus L.)-rice (Oryza sativa L.) rotation. Plant and Soil 320: 141-151.

https://doi.org/10.1007/s11104-008-9879-7 


\section{AGRICULTURAL AND FOOD SCIENCE}

I. Keres et al. (2020) 29: 210-221

Mäder, P., Edenhofer, S., Boller, T., Wiemken, A. \& Niggli, U. 2000. Arbuscular mycorrhizae in a long-term field trial comparing low-input (organic, biological) and high-input (conventional) farming systems in a crop rotation. Biology and Fertility of Soil 31 : 150-6. https://doi.org/10.1007/s003740050638

Methods of Soil and Plant Analysis 1986. Agricultural Research Centre, Department of Soil Science. Jokioinen, Finland. 45 p.

Murugappan, V., Latha, M.R., Jagadeeswaran, R., Bhaskaran, A. \& Malarvizhi, P. 2007. Balanced fertiliser use for sustaining soil fertility and maximizing crop yield - A review. Agricultural Reviews 28: 254-261. https://www.researchgate.net/publication/267250173/. Accessed 08 May 2019.

Nardi, S., Morari, F., Berti, A., Tosoni, M. \& Giardini, L. 2004. Soil organic matter properties after 40 years of different use of organic and mineral fertilisers. European Journal of Agronomy 21: 357-367. https://doi.org/10.1016/j.eja.2003.10.006

Oehl, F., Sieverding, E., Ineichen, K., Mäder, P., Boller, T. \& Wiemken, A. 2003. Impact of land use intensity on the species diversity of arbuscular mycorrhizal fungi in agroecosystems of central Europe. Applied and Environmental Microbiology 69: $2816-24$. https://doi.org/10.1128/AEM.69.5.2816-2824.2003

Ricroch, A., Harwood, W., Svobodová, Z., Lászlo Sagi, L., Elena, P., Badea,M., Rosca, I., Cruz, G., Pedro M., Fevereiro, S., Riera, V.M., Jansson, S., Morandini, P., Bojinov, B., Cetiner, S., Custers, R., Schrader, U., Jacobsen, H.-J., Martin-Laffon, J., Audrey Boisron, A. \& Kuntz, M. 2016. Challenges facing European agriculture and possible biotechnological solutions. Critical Reviews in Biotechnology 36: 875-883. https://doi.org/10.3109/07388551.2015.1055707

Roostalu, H. 2012. Physical and chemical properties of soil. In: Astover, A. (ed). Soil Science. Tartumaa: Greif. p. 122-123. (in Estonian). Sardans, J. \& Penuelas, J. 2015. Potassium: A neglected nutrient in global change. Global Ecology and Biogeogrphy 24: $261-275$. https://doi.org/10.1111/geb.12259

Srinivasarao, Ch. \& Srinivas, K. 2017. Potassium dynamics and role of non-exchangeable potassium in crop nutrition. Indian Journal of Fertilisers 13: 80-94. https://www.researchgate.net/publication/315846042

Tein, B., Kauer, K., Eremeev, V., Luik, A., Selge, A. \& Loit, E. 2014. Farming systems affect potato (Solanum tuberosum L.) tuber and soil quality. Field Crop Research 156: 1-11. https://doi.org/10.1016/j.fcr.2013.10.012

Vanden Nest, T., Ruysschaert, G., Vandecasteele, B., Cougnon, M., Merckx, R. \& Reheul, D. 2015. P availability and P leaching after reducing the mineral $P$ fertilization and the use of digestate products as new organic fertilizers in a 4-year field trial with high P status. Agriculture, Ecosystems and Environment 202: 56-67. https://doi.org/10.1016/j.agee.2014.12.012

Wander, M. 2015. Soil Fertility in Organic Farming Systems: Much More than Plant Nutrition. Organic Agriculture. https://eorganic.org/node/787/. Accessed 08 May 2019.

Watson, C.A., Atkinson, D., Gosling, P., Jackson, L.R. \& Rayns, F.W. 2002. Managing soil fertility in organic farming systems. Soil Use and Management 18: 239-247. https://doi.org/10.1111/j.1475-2743.2002.tb00265.x

Weber, J., Karczewska, A., Drozd, J., Licznar, M., Licznar, S., Jamroz, E. \& Kocowicz, A. 2007. Agricultural and ecological aspects of a sandy soil as affected by the application of municipal solid waste composts. Soil Biology and Biochemistry 39: 1294-1302. https://doi.org/10.1016/j.soilbio.2006.12.005

Yadav, R.L., Dwivedi, B.S. \& Pandey, P.S. 2000. Rice-Wheat Cropping System: Assessment of Sustainability under Green Manuring and Chemical Fertilizer Inputs. Field Crops Research 65: 15-30. https://doi.org/10.1016/S0378-4290(99)00066-0 